\title{
Our New Hony. Secretary
}

Mr. J. C. Shahani

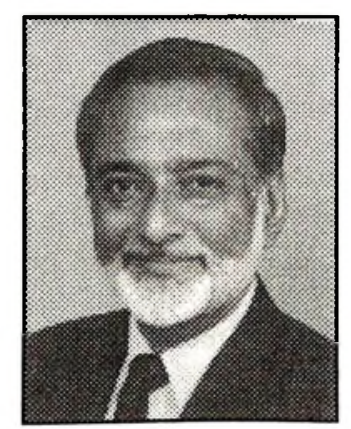

Born in January 1944, Shri Shahani is a graduate in mechanical engineering, Life Fellow Member of both our Institute and the Institution of Engineers, member of the Welding \& Joining Society of the U.K. and American Welding Society, and served on the Advisory Panel of the Surface Engineering Journal, UK and CSWIP Overseas Liaison Group. He was nominated by IIW on Sectional Standards Committee SMDC 15, Bureau of Indian Standards.

He began his career over 34 years ago as development engineer for prototype of 49c.c. Moped undertaken at CMERI, Durgapur, followed by senior management positions upto 1973 in DCM Group chemicals, plastics and fertiliser units in Delhi, Daurala, Kota and Madras. In 1973, Shri Shahani took over as General Manager, P.D.Industries, Calcutta where he developed, designed and produced special arc-welding electrodes used for hard surfacing, S.S, C.I. and metal cutting. He had a long innings well recognised for several weld repair applications successfully achieved for the first time in industry. This included developing renowned weld metal combinations (Maggy 34CR/Stainly 28) consistently giving over $300 \%$ life of components in service condition of combined impact and abrasive wear. In 1980 he became Partner in P.D. Industries, and founded WATSCO - Welding \& Technical Services Co. in 1985. He continues to lead WATSCO through application of special welding products imported by industry, and as TWl's Consultant in India enhancing $\mathrm{R} \& \mathrm{D}$, consultancy and training and certification activities.

During his 25 years as IIW member he has actively supported our Institute and its programmes. From 1976 onwards he was member of G.P. Committee, IWC96 Technical Committee, Executive Committee-Calcutta Branch, Finance Committee, Council Member, Faculty for Welding Appreciation Courses, and closely involved with branch formation process in Jamshedpur and Baroda. In 1997-99 he was Chairman-G.P.Committee and Chairman-IWC99 Coordination and Registration. He continues as Council Member having been elected Honorary Secretary of our Institute on 8 January 2000.

Shri Shahani has presented several papers to Tata Management Development Centre, National Productivity Council and technical societies in India and abroad. He helped spread the hardfacing approach through newspaper articles and "welders clinics" directed by him at site, in coalfields, iron ore mines, cement, thermal power and mineral processing industries across India. He has visited welding R\& D units in Austria, Belgium, USA, Denmark, UK, Singapore, Holland, Norway, Sweden, Germany etc. and attended International Institute of Welding Annual Assembly, AWS Welding Show, Japan Welding Show, among other international events. 